\title{
COMPARATIVE PERFORMANCE OF POLYMERIC XYLENOL TETRASULFIDE VERSUS CREOSOTE IN AN AWPA E7 FIELD STAKE TEST
}

\author{
Darrel D. Nicholas ${ }^{1, \wedge}$ \\ Amy Rowlen \\ David Milsted $^{1}$
}

\begin{abstract}
A need exists to develop new organic, environmentally benign wood preservatives for industrial applications to replace the older creosote and pentachlorophenol systems. In this study the performance of creosote at three retentions was compared to a new wood preservative candidate formulated with Polymeric Xylenol Tetrasulfide (PXTS) in an E7 AWPA field study using two sets of southern pine and yellow poplar field stakes treated with three creosote retentions or five retentions of PXTS. The stakes were installed at two test sites and evaluated after 3,5 years, 6 years, and 14 years exposure. After six years of exposure at both sites, which is double the minimum recommended exposure period of three years' field data for AWPA submission of a proposed new preservative system, the average decay ratings data for southern pine stakes after three years exposure was not sufficient to definitively determine which system provides superior protection against decay and termite attack (Creosote at the AWPA UC4B pole retentions versus pine stakes treated with much lower PXTS levels). However, after a longer exposure time of 14 years the data conclusively shows that pine stakes treated to the utility pole AWPA UC4B creosote retention performed poorer at both sites against decay and termite degradation than pine stakes treated with $26 \mathrm{Kg} / \mathrm{m}^{3}$ PXTS. Similar results were obtained with the yellow poplar stakes. We conclude that: 1) much longer E7 exposure times are necessary then the minimum recommended three years in the AWPA GDA Standard for submission of new systems to definitively determine the efficacy of a proposed oil borne system compared to the efficacy of a traditional organic preservative for commercial applications, and 2) long term field PXTS performance against decay and termite deterioration is equal or greater than that obtained with creosote at about four times the PXTS retention.
\end{abstract}

Keywords: Creosote, decay, field stake test, polymeric xylenol tetrasulfide, termites, wood preservation.

\section{INTRODUCTION}

Due to environmental concerns, there is a need to develop new environmentally benign organic wood preservatives that have low mammalian toxicity for industrial applications such as utility poles. One possible candidate is Polymeric Xylenol Tetrasulfide (PXTS). The synthesis and properties of PXTS are described in two patents, Goswami et al. 1999a and Goswami et al. 2001. Like the organic creosote and pentachlorphenol (penta) preservatives which have long been employed for commercial applications, PXTS is an organic preservative but does not have the associated human exposure and environmental issues. PXTS is not currently registered as a wood preservative by EPA but preliminary studies by Akzo Nobel indicate that PXTS has a lower mammalian toxicity profile than creosote. 
PXTS has been evaluated as a potential wood preservative in a number of laboratory and field tests, with the data presented in several publications (Goswami et al. 1999b, Goswami et al. 2000, Goswami et al. 2002). These initial efficacy studies clearly showed that the wood preservative performance of PXTS is superior to creosote. Furthermore, after 63 months of exposure in a field stake test at the MSU Dorman Lake and Saucier MS test plots, PXTS treated pine stakes provided considerably better performance than creosote (Freeman et al. 2004). In the years 2000 to 2006 Akzo Nobel conducted extensive research in an attempt to commercialize PXTS as a wood preservative for residential decking using an oilborne formulation. However, bleeding problems was a major detrimental issue and the project was terminated. Since then, no further commercialization activities have developed.

The objective of this article is to provide information on another E7 field stake test comparing the efficacy of creosote versus PXTS in long term field trials conducted at two locations in Mississippi.

\section{MATERIALS AND METHODS}

The field stake test was carried out in accordance with AWPA Standard E7-15 (2015) using ten $19 \mathrm{~mm} x$ $25 \mathrm{~mm}$ x $406 \mathrm{~mm}$ southern pine (Pinus taeda L.) and yellow poplar (Liriodendron tulipifera L.) defect-free sapwood stakes for each retention level. Toluene was used as a diluent for all creosote and PXTS treatments. PXTS was formulated using a P9-A treating oil obtained from Imperial Oil Ltd which was diluted with toluene to provide at 15 weight \% solution for both the PXTS and P9 A solvent control stakes. Creosote served as the positive controls. The stakes were treated by a full cell process $(95 \mathrm{KPa}$ vacuum for 30 minutes followed by $1060 \mathrm{KPa}$ pressure for 60 minutes), with the retentions determined by weight gain and active concentration in the treating solution. After treatment the stakes were air dried in the laboratory until the volatile toluene solvent had evaporated.

The creosote pine stakes were treated to three retention levels $48 \mathrm{~kg} / \mathrm{m}^{3}, 96 \mathrm{~kg} / \mathrm{m}^{3}$ and $120 \mathrm{~kg} / \mathrm{m}^{3}$. The PXTS pine stakes were treated to five retentions of $21 \mathrm{~kg} / \mathrm{m}^{3}, 26 \mathrm{~kg} / \mathrm{m}^{3}, 34 \mathrm{~kg} / \mathrm{m}^{3}, 42 \mathrm{~kg} / \mathrm{m}^{3}$, and $50 \mathrm{~kg} / \mathrm{m}^{3}$ with the retentions selected on the basis of prior efficacy tests which indicated that PXTS was approximately two to three times as effective as creosote. The yellow poplar stakes were treated with creosote to retentions of approximately $48 \mathrm{~kg} / \mathrm{m}^{3}, 102 \mathrm{~kg} / \mathrm{m}^{3}$ and $157 \mathrm{~kg} / \mathrm{m}^{3}$. The yellow poplar stakes were treated with PXTS to approximately $18 \mathrm{~kg} / \mathrm{m}^{3}, 24 \mathrm{~kg} / \mathrm{m}^{3}, 32 \mathrm{~kg} / \mathrm{m}^{3}, 41,6 \mathrm{~kg} / \mathrm{m}^{3}$ and $51,3 \mathrm{~kg} / \mathrm{m}^{3}$. The PXTS formulation consisted of 15 weight \% P9 A oil in toluene, with a 15:85 P9 A/toluene mixture employed to treat the solvent controls. Sets of 10 replicate stakes per site for each formulation, along with untreated controls and P9 A solvent controls, were installed using a randomized plot design at the Dorman Lake MS and Saucier MS test sites. These two test sites have been used extensively for over 40 years for evaluating candidate wood preservatives. For example, a study entitled Comparative performance of pentachlorophenol and copper naphthenate in a longterm field stake test was published by Nicholas and Freeman in 2000. The Dorman test plot is classified as a severe Sheffer hazard class 5 for decay and termite activity and the Saucier test plot is classified as a high hazard class 4 site. These test sites have been used for numerous tests over the years.

The Dorman Lake site is located in the Upper Coastal Plain region of northeast Mississippi near Mississippi State University (MS). A Falkner soil (Aquic Paleudalf) comprises the forested site. Falkner soils are deep, somewhat poorly drained, acid soil with a silt loam surface horizon and clayey subsoils. The Saucier test plot is located in the Harrison National Forest in the Lower Coastal Plain region of southern Mississippi. The forested Saucier site has a McLaurin soil (Typic Paleudult) which is deep, well drained and strongly acidic with a loamy sand surface texture and loamy subsoils. The Falkner Dorman Lake silt loam surface horizon has $622 \%$ more clay, $263 \%$ more silt, and $645 \%$ less sand contents than the coarser textured McLaurin soil at the Saucier site. The Dorman Lake soil is very strongly acidic with a pH of 4,8 while the soil at Saucier has a $\mathrm{pH}$ of 5,12. Dorman Lake has fair copper tolerant fungal activity and moderate termite activity, while the Saucier site has high termite activity and being near the Gulf Coast, a mild winter and a long and relatively wet summer. The stakes were rated for decay and termite deterioration as per AWPA Standard E7-15 (2015), with the average ratings reported after 42 months, 74 months, and 168 months of exposure. 


\section{RESULTS AND DISCUSSION}

The average decay and termite ratings for the pine stakes exposed at the Dorman Lake and Saucier test plots are presented in Table 1 and Table 2, respectively.

Table 1: Average decay and termite ratings for pine stakes exposed at dorman lake.

\begin{tabular}{|c|c|c|c|c|c|c|}
\hline \multirow{2}{*}{$\begin{array}{l}\text { Treatment } \\
\mathrm{kg} / \mathrm{m}^{3} \text { (a.i.) }\end{array}$} & \multicolumn{2}{|c|}{42 Months } & \multicolumn{2}{|c|}{74 Months } & \multicolumn{2}{|c|}{168 Months } \\
\hline & Decay & Termites & Decay & Termites & Decay & Termites \\
\hline Creosote $(49 \pm 5)$ & 9,3 & 9,7 & 9,0 & 8,5 & 1,6 & 5,7 \\
\hline Creosote $(97 \pm 8)$ & 9,8 & 10 & 9,5 & 9,2 & 3,6 & 7,4 \\
\hline Creosote $(120 \pm 11)$ & 10 & 10 & 9,8 & 9,8 & 6,1 & 8,1 \\
\hline PXTS (20 \pm 2$)$ & 9,6 & 9,5 & 9,9 & 8,7 & 7,3 & 7,5 \\
\hline PXTS (25 \pm 2$)$ & 9,9 & 9,8 & 10 & 9,1 & 8,5 & 8,5 \\
\hline PXTS (34 \pm 3$)$ & 9,9 & 10 & 9,9 & 9,3 & 9,5 & 9,1 \\
\hline P XTS $(42 \pm 5)$ & 10 & 9,9 & 10 & 9,3 & 9,5 & 9,1 \\
\hline PXTS (49 \pm 5$)$ & 9,9 & 9,9 & 9,9 & 9,5 & 9,7 & 9,9 \\
\hline Solvent Control & 8,9 & 9,5 & 7,2 & 5,6 & 1,2 & 1,0 \\
\hline Untreated & 0 & 0 & 0 & 0 & 0 & 0 \\
\hline
\end{tabular}

Table 2: Average decay and termite ratings for pine stakes exposed at saucier.

\begin{tabular}{|c|c|c|c|c|c|c|}
\hline \multirow[t]{2}{*}{ Treatment $\mathrm{kg} / \mathrm{m}^{3}$} & \multicolumn{2}{|c|}{42 Months } & \multicolumn{2}{|c|}{74 Months } & \multicolumn{2}{|c|}{168 Months } \\
\hline & Decay & Termites & Decay & Termites & Decay & Termites \\
\hline Creosote $(49 \pm 5)$ & 9,9 & 9,1 & 9,0 & 8,5 & 1,5 & 2,5 \\
\hline Creosote $(97 \pm 8)$ & 9,9 & 9,9 & 9,5 & 9,2 & 8,0 & 8,7 \\
\hline Creosote $(120 \pm 11)$ & 9,9 & 10 & 9,8 & 9,8 & 7,5 & 6,7 \\
\hline PXTS (20 \pm 2$)$ & 9,9 & 9,9 & 9,9 & 8,7 & 6,7 & 5,7 \\
\hline PXTS $(25 \pm 2)$ & 9,9 & 10 & 10 & 9,1 & 8,5 & 8,0 \\
\hline PXTS $(34 \pm 3)$ & 10 & 9,9 & 9,9 & 9,3 & 9,3 & 8,7 \\
\hline P XTS $(42 \pm 5)$ & 10 & 10 & 10 & 9,3 & 8,9 & 8,9 \\
\hline PXTS $(49 \pm 5)$ & 10 & 9,9 & 9,9 & 9,5 & 9,1 & 9,3 \\
\hline Solvent Control & 9,1 & 7,2 & 7,2 & 5,6 & 5,1 & 4,0 \\
\hline Untreated & 0 & 0 & 0 & 0 & 0 & 0 \\
\hline
\end{tabular}

The average decay ratings for the creosote treated pine stakes at Dorman Lake at the $96 \mathrm{~kg} / \mathrm{m}^{3}$ and 100 $\mathrm{kg} / \mathrm{m}^{3}$ treatment levels, which correspond to the UC4A and UC4B pole creosote retentions respectively, show good efficacy ratings of above 9,0 after 3,5 years and 6 years of exposure. Similar ratings were obtained with the four highest PXTS retentions of $26 \mathrm{~kg} / \mathrm{m}^{3}$ or greater. Consequently, after these exposure times of 3,5 years and 6 years, which are longer than the minimum recommended exposure period of three years E7 data that is suggested for submission of a new proposed preservative (AWPA GDA 2017 Standard), it is not possible to determine which system gives better performance. The same inability to compare the performance of the E7 pine stakes also occurs for the Saucier test plot after 3,5 years and 6 years exposure.

After 168 months (14 years) of exposure the differences in decay and termite efficacies between creosote at UC4A and UC4B pole retentions versus PXTS are clearly evident. For the pine stakes at Dorman Lake the data in Table 1 shows that the PXTS performance after 74 months exposure at the lowest retention of 20,8 $\mathrm{kg} / \mathrm{m}^{3}$ is approximately equivalent in decay efficacy as creosote at the $120 \mathrm{~kg} / \mathrm{m}^{3} \mathrm{UC} 4 \mathrm{~B}$ pole retention level. Furthermore, the average decay ratings for creosote at the UC4A and UC4B pole retentions were both below 7.0 which indicates efficacy concerns (AWPA Standard E7-15). By contrast, all five PXTS retentions resulted in average decay and termite ratings at Dorman Lake that were above 7,0 after 168 months, with the three highest PXTS retentions all having average decay and termite ratings greater than 9,0. At the Saucier test site, the PXTS performance after the long exposure time of 14 years, the stakes treated at a retention of $26 \mathrm{~kg} / \mathrm{m}^{3}$ are performing better than creosote at the UC4B retention of $120 \mathrm{~kg} / \mathrm{m}^{3}$. Thus, at both test sites with pine stakes, 
PXTS clearly provides greater decay and termite protection compared to creosote at about four times the PXTS level after 14 years. The data also shows that the difference in performance of the two preservative systems is not discernable on the basis of the 3,5 years and 6 year of exposure data.

The data for the yellow poplar stakes at the Dorman Lake test site is presented in Table 3 and for Saucier in Table 4, with the highest creosote retention of about $157 \mathrm{~kg} / \mathrm{m}^{3}$ which is slightly greater than the UC4C pole retention of $144 \mathrm{~kg} / \mathrm{m}^{3}$.

Table 3: Average decay and termite ratings for yellow poplar stakes exposed at dorman lake.

\begin{tabular}{|c|c|c|c|c|c|c|}
\hline \multirow{2}{*}{$\begin{array}{l}\text { Treatment } \\
\mathrm{kg} / \mathrm{m}^{3} \text { (a.i.) }\end{array}$} & \multicolumn{2}{|c|}{42 Months } & \multicolumn{2}{|c|}{74 Months } & \multicolumn{2}{|c|}{168 Months } \\
\hline & Decay & Termites & Decay & Termites & Decay & Termites \\
\hline Creosote $(49 \pm 3)$ & 9,4 & 10 & 9,3 & 9,8 & 0,0 & 6,4 \\
\hline Creosote $(102 \pm 9)$ & 9,8 & 9,9 & 9,8 & 8,9 & 4,6 & 8,2 \\
\hline Creosote $(157 \pm 16)$ & 9,8 & 9,9 & 9,4 & 9,1 & 7,1 & 9,3 \\
\hline PXTS (18 \pm 3$)$ & 9,9 & 10 & 9,1 & 8,1 & 6,6 & 5,4 \\
\hline PXTS $(21 \pm 2)$ & 9,9 & 9,9 & 9,6 & 8,9 & 5,6 & 5,4 \\
\hline PXTS (32 \pm 2$)$ & 9,9 & 10 & 9,6 & 9,0 & 8,3 & 8,2 \\
\hline P XTS $(38 \pm 8)$ & 9,9 & 9,9 & 9,9 & 9,0 & 8,1 & 7,6 \\
\hline PXTS (52 \pm 5$)$ & 10 & 10 & 9,0 & 9,0 & 8,7 & 8,9 \\
\hline Solvent Control & 5,8 & 5,8 & 4,3 & 4,3 & 0,9 & 1,6 \\
\hline Untreated & 0 & 0 & 0 & 0 & 0 & 0 \\
\hline
\end{tabular}

Table 4: Average decay and termite ratings for yellow poplar stakes exposed at saucier.

\begin{tabular}{|c|c|c|c|c|c|c|}
\hline \multirow{2}{*}{$\begin{array}{c}\text { Treatment } \\
\mathrm{kg} / \mathrm{m}^{3} \text { (a.i.) }\end{array}$} & \multicolumn{2}{|c|}{42 Months } & \multicolumn{2}{|c|}{74 Months } & \multicolumn{2}{|c|}{168 Months } \\
\hline & Decay & Termites & Decay & Termites & Decay & Termites \\
\hline Creosote $(49 \pm 3)$ & 9,7 & 10 & 9,3 & 9,8 & 4,0 & 4,7 \\
\hline Creosote $(102 \pm 9)$ & 9,9 & 10 & 9,8 & 8,7 & 8,4 & 7,5 \\
\hline Creosote $(157 \pm 16)$ & 9,9 & 9,8 & 9,9 & 9,1 & 8,0 & 8,8 \\
\hline PXTS $(18 \pm 3)$ & 9,8 & 9,5 & 9,1 & 8,1 & 4,0 & 6,0 \\
\hline PXTS $(21 \pm 2)$ & 10 & 9,5 & 9,6 & 8,9 & 5,4 & 3,6 \\
\hline PXTS $(32 \pm 2)$ & 9,8 & 9,6 & 9,6 & 9,0 & 8,3 & 8,5 \\
\hline P XTS (38 \pm 8$)$ & 9,9 & 9,6 & 9,9 & 9,0 & 9,0 & 8,3 \\
\hline PXTS $(52 \pm 5)$ & 10 & 9,8 & 9,0 & 9,0 & 8,8 & 9,3 \\
\hline Solvent Control & 3,8 & 5,7 & 4,3 & 4,3 & 0,9 & 1,6 \\
\hline Untreated & 0 & 0 & 0 & 0 & 0 & 0 \\
\hline
\end{tabular}

Like the pine stakes, the efficacy data for the yellow poplar stakes is insufficient after 42 months and 74 months of exposure to determine the comparative efficacy of PXTS versus creosote. However, after 168 months of exposure sufficient data is available to establish approximate toxic threshold values for creosote and PXTS. Specifically, at the Dorman Lake test site (Table 3) the long-term performance of yellow poplar stakes treated with PXTS at $32 \mathrm{~kg} / \mathrm{m}^{3}$ is roughly equivalent to creosote at $157 \mathrm{~kg} / \mathrm{m}^{3}$. For the Saucier test site (Table 4) the performance of yellow poplar treated with PXTS at $35 \mathrm{~kg} / \mathrm{m}^{3}$ is about equivalent to creosote at $154 \mathrm{~kg} / \mathrm{m}^{3}$. Thus, like the pine stake data discussed above, PXTS provides approximatelyequivalentlong-termefficacy tothat ofcreosoteatonlyaboutone-fourth thecreosoteretentionlevels. 


\section{CONCLUSIONS}

This long term AWPA E7 field state study at two test plots in Mississippi demonstrated that PXTS is an effective wood preservative for both pine and yellow poplar at treatment levels lower than those required for creosote. Furthermore, in order to define a clear comparison between the efficacy of these two preservatives an exposure period of greater than six years was required. The need for extended exposure time for field stakes beyond the AWPA standard recommendations has been addressed in previous publications by Schultz and Nicholas (2009) as well as Lebow et al. (2008). This present study reinforces the need for longer exposure times in order to provide a clear differentiation in the performance of wood preservatives used for soil contact applications.

\section{ACKNOWLEDGEMENTS}

This publication is a contribution of the Forest and Wildlife Research Center, Mississippi State University. FWRC/MAFES Publication No. SB1026.

\section{REFERENCES}

AWPA. 2015. E7-15: Standard field test for evaluation of wood preservatives to be used in ground contact (UC4A, UC4B, UC4C) stake test. American Wood Protection Association Book of Standards. American Wood Protection Association: Birmingham, AL., USA.

AWPA. 2017. Guidance Document A. Data requirement guidelines for listing wood preservatives in the AWPA Standards. American Wood Protection Association: Birmingham, AL., USA https://awpa.com/about/ governance

Freeman, M.H.; Nicholas, D.D.; Rentz, R.; Buff, R. 2004. PXTS: A Metal Free Oligomer Wood Preserving System. A summary of data to date. International Group on Wood Preservation. Document No. IRG/ WP 0430350 .

Goswami, J.; Abramson, A.; Buff, R.; Nicholas, D. 1999a. Polymeric Alkylphenol Polysulfide - A new wood preservative compound. International Research Group on Wood Preservation. IRG/WP 99-30193.

Goswami, J.; Liu, J.; Doyle, A.K. 1999b. Wood preservation utilizing polymeric phenol sulfide. U.S Patent No. 5,925,424. U.S Patent Office: Washington, D.C., USA. https://patentimages.storage.googleapis. com/52/7b/7c/8948d34a428b3d/US5925424.pdf

Goswami, J.; Abramson, A.; Buff, R.; Nicholas, D. 2000. Evaluation of Polymeric Alkylphenol Polysulfide as a new wood preservative compound. International Research Group on Wood Preservation. Document No. IRG/WP 0030251.

Goswami, J.; Liu, J.; Doyle, A.K. 2001. Process for making polymeric phenol sulfate. U.S. Patent No. 6303746. U.S. Patent and Trademark Office: Washington, D.C., USA. https://patentimages.storage.googleapis. com/15/ab/9f/ccbca29666394e/US6303746.pdf

Goswami, J.; Abramson, A.; Buff, R.; Nicholas, D.; Schultz, T. 2002. Update on lab and field results from wood treated with polymeric alkylphenol polysulfide. International Research Group on Wood Preservation. Document No. IRG/WP 0240240.

Lebow, S.; Woodward, B.; Lebow, P. 2008. Observations on the predictive value of short-term stake tests. In Proceedings, $104^{\text {th }}$ Annual meeting of the American Wood Protection Association: Birmingham, AL., USA. 104: 85-88. https://www.fpl.fs.fed.us/documnts/pdf2008/fpl_2008_lebow003.pdf

Nicholas, D.D.; Freeman, M.H. 2000. Comparative performance of pentachlorophenol and copper naphthenate in a long-term field stake test. Document No. IRG/WP 00-30243. 
Schultz, T.P.; Nicholas, D.D. 2009. Short-and long-term ground contact decay efficacies of three copper-based systems and possible implications for standardization criteria for copper-based systems. Forest Prod $J$ 50:13-18. https://www.fwrc.msstate.edu/pubs/10547.pdf 